\title{
Human Resource Management Strategies for Overcoming the Barriers in Cross- border Acquisitions of Multinational Companies: the Case of Multinational Subsidiaries in Poland
}

\author{
Małgorzata Rozkwitalska
}

Management Department, Gdansk School of Banking, Żabi Kruk 12 str., 80-822 Gdansk, Poland

crossref http://dx.doi.org/10.5755/j01.ss.77.3.2009

\begin{abstract}
The aim of the paper is to portrait some winning as well as failing strategies in human resource management (HRM) in cross-border acquisitions in Poland. The focus is on barriers to interactions in cross-border acquisitions that affect personnel management. There is an assumption that effective overcoming of these barriers reduces tensions in interpersonal relationships in acquisitions and thus contributes to the winning HRM strategies. The author tries to identify the determinants of successful approaches to managing interactions of people within foreign subsidiaries of multinational companies (MNCs) established via acquisitions, basing on the cases from Poland.
\end{abstract}

Keywords: cross-border acquisitions, foreign subsidiaries, barriers, human resource management.

\section{Introduction}

Mergers and acquisitions (M\&As) play a significant role in turbulent times. Nowadays, after the outbreak of world crisis, their role appears to be even greater, especially in cross-border transactions. Cross-border M\&As involve cooperation between the parties from different cultures and must overcome many obstacles. Studies have shown that there is a plethora of crosscultural challenges in cross-border M\&As (Stahl, 2006). Such challenges seem to be even greater in the context of Central and East Europe (CEE) countries which have been involved in a transition process of their economic system. With the opening of their economies these countries have been faced with buyout of state-owned enterprises by foreign investors. Once they were bought, they became foreign subsidiaries of multinational companies (MNCs). These foreign units were burdened, among other things, with the socialistic administrative heritage and the excess of ineffective human resources including obsolete managerial practices. Together with cultural distance between a parent enterprise and its subsidiary it has increased the complexity of managing the overseas unit and interpersonal relations within a MNC including transfer of human resource management (HRM) practices, organisational learning, employment relations, and expatriates functioning within subsidiaries (Steger et al., 2011).

A successful HRM in cross-border M\&As requires an in-depth understanding of barriers to interpersonal relationships in the management of foreign subsidiaries. Managers are expected to learn how to overcome such barriers to reduce tensions in interpersonal relations. Even though studies referring to HRM issues in MNCs are relatively common, those that focus on barriers in managing foreign subsidiaries in transition economies in Europe are rather rare. Most research on foreign subsidiaries covers one of the following problems: the relationship between strategy and structure of MNCs, the headquarters-subsidiary relationships including centralisation, formalisation, coordination and integration; the processes of strategic decision making and organisational change in MNCs, the subsidiary role and its evolution over time, the flows of information between the subsidiary and its network (Birkinshaw, 2003). The subsidiary's perspective in studying cross-border issues in M\&As is relatively uncommon. Thus, this paper highlights the relationships between barriers in foreign subsidiaries of MNCs established via acquisitions and interpersonal relations. It emphasises that there are barriers that affect personnel management. Effective overcoming of such barriers contributes to successful interpersonal interactions and thus, effective HRM practices. The major aim of this paper is to portrait selected approaches in HRM in crossborder acquisitions in Poland, one of the transition economies in CEE. The author's findings can also contribute to a better understanding of cross-cultural challenges in cross-border acquisitions in transition economies. Moreover, the author tries to identify the determinants of successful approaches to managing interactions of people within foreign subsidiaries of MNCs established via acquisitions.

The first section of the paper provides the existing literature review on M\&As. The emphasis here is placed on the impact of cultural challenges and the human side on the success or failure of cross-border acquisitions, whereas suggestions how to manage them 'culturally' are also discussed. The second part emphasises the sources and types of barriers in cross-border acquisitions based on the author's concept. The subsequent section presents details 

in Poland

concerning the research method, namely the sample characteristic, explanation on the main and additional research questions, and the instrument. Then, the research findings with respect to the barriers to personnel management in selected foreign subsidiaries in Poland are portrayed. Additionally, the successful approaches to manage such barriers are also discussed. The paper ends up with a conclusion on what may determine a successful integration process with regards to a human side from the cross-border interactions' point of view. The propositions were constructed concerning the author's empirical findings. The limitations of the findings and suggestions for further research are also discussed.

\section{Literature review on cultural challenges and HRM issues in cross-border acquisitions}

There is sound evidence that cross-border acquisitions face significant cross-cultural challenges (e.g. Stahl, 2006; Lodorfos and Boateng, 2006). Acquisitions themselves impose stress on the employees due to a potential restructuration and downsizing, and reduce their efficiency (Shook and Roth, 2011), while cross-border deals 'add another layer of complexity to the merger process' (Kanter and Corn, 1994, p. 10). The differences in cultures both national and organisational lead to integration problems. People in acquired companies tend to feel confused since they are not certain which behaviours are accepted and they are afraid of losing their jobs. The workplace environment becomes chaotic. Therefore, most studies have stressed the negative impact of M\&As on people like low employee morale, a decrease in the satisfaction level, an increase in unproductive work time, errors, absenteeism, and sabotage (Bourantas and Nicandrou, 1998). HRM practices may have 'significant effect on acquirer's ability to get the best results of the new subsidiary' (Antila and Kakkonen, 2008, p. 281). Consequently, appropriate HRM approaches should be implemented in pre-integration, integration, and postintegration processes (Schuler and Jackson, 2001).

Cultural fit between merging companies proves to be a key factor in M\&As' success and therefore should receive enough attention at all stages of M\&As (Lodorfos and Boateng, 2006; Bourantas and Nicandrou, 1998). Shared culture contributes to mutual trust between parties. It bridges members of merging companies, creates a sense of cohesion which can further support synergy in the deal (Cartwright and Cooper, 1993; Kanter and Corn, 1994). In contrast to that, cultural barriers can hamper information flow and knowledge transfer and thus negatively affect a M\&A's performance (Buckley and Casson 1996). Culture acts as a key factor in a socialisation process which teaches organisational members how to behave accordingly. Thus, a number of studies suggest that cultural differences between an acquirer and an acquired party leading to human-related problems are a major cause of acquisitions' failure (e.g. Bijlsma-Frankema, 2001; Krishnan et al., 2004; Huang and Kleiner, 2004).
Resistance is people's natural reaction to the situation of being acquired. The authors have referred to this reaction as a 'cultural clash' (e.g. Brock et al., 2000). It has been proved that cultural clash limits commitment and cooperation between the employees, reveals withdrawal among them and increases a turnover rate among the managers in acquired firms. These further negatively affect the shareholder value and the operational performance. The failure rate of M\&As due to cultural clash has been estimated between a quarter to half (Davy et al., 1988). In spite of that fact, cultural factors, while appreciated by scholars, have seemed to be neglected by practitioners who often give little attention to cultural aspects of M\&As, especially in the pre-merger stage (Lodorfos and Boateng, 2006).

Stahl and Voigt (2008) noticed that two factors in the integration process are critical for synergy and thus success or failure of M\&As. These are task integration and sociocultural integration. While the first one refers to the transfer of capabilities and resource sharing, the second one involves developing a sense of unity and positive attitude toward the new company among the employees. Cultural differences affect both task integration and sociocultural integration, and thus outcomes of acquisitions. Cultural similarities facilitate the emergence of trust and limits conflicts. On the contrary, a cultural distance due to a social categorisation process increases a negative perception of the out-group members, reinforcing 'us-versus-them' thinking as well as various biases which are likely to be greater when an acquisition is perceived as a threat and when there are cultural differences between the companies. Consequently, cultural differences are negatively associated with sociocultural integration outcomes. Nevertheless, cultural differences may also create opportunities for learning due to access to valuable capabilities embedded in different cultures. Therefore, cross-border acquisitions due to cultural differences offer access to unique capabilities, knowledge, learning and innovations. They also motivate managers to pay more careful attention to the human resources aspect within their companies (Stahl and Voigt, 2008; Stahl, 2006). However, the successful transfer of knowledge, resource sharing and learning can be achieved only if the distance between the merging companies is not so large. Therefore, there is an interaction between task integration and sociocultural integration. As Stahl and Voigt (2008) concluded, although cultural factors may strengthen the potential for synergies resulting from task integration, cultural differences that affect sociocultural integration are likely to have an adverse effect on the realisation of assumed synergies. Thus, Stahl and Voigt (2008) later inferred that cultural differences' impact on the success of an acquisition depends on the level of integration required. Only in M\&As that require high levels of operational integration cultural differences create barriers in postmerger integration period including human-related problems. Furthermore, if an acquirer is perceived as a saviour by the target organisation and there is business 

in Poland

compatibility between the merging companies, cultural issues are not problematic (Kanter and Corn, 1994).

Lodorfos and Boateng (2006) proposed a framework for managing cultural challenges in M\&As. They suggest managers pay more attention to cultural issues at the early stages of merger process. They recommend the target organisation's employees' representation and participation in the pre-merger stage to ensure trust and reduce risk of cultural clash. They also suggest implementing a job rotation system among the key managers of merging firms to bridge the gap between the organisations and implement the best practices from them. Furthermore, re-engineering of communication and information flow processes and systems is necessary to limit stress and uncertainty of the employees. They conclude that communication seems to be decisive in building trust between merging companies, which is coherent with prior empirical findings of Kanter and Corn (1994), who also notice that open communication and showing respect are critical to the success of M\&As due to contribution in trust building. Moreover, they recommend fostering relationship desirability, reducing uncertainty, showing respect to people, and promoting business success. Kanter and Corn (1994) suggest involving HR personnel in playing the role of change agent, which includes evaluation of employees' skills and competencies in the early stages of the integration, working with them, providing information and creating new channels for knowledge transfer. At the same time, Kanter and Corn (1994) argue that the involvement of HR professionals in the early stage of merger process is rare. Salama et al. (2003) identified a key success factor in three cross-border M\&As. These were the creation of integration team, culture assessment before the deal is completed, the awareness of common set of goals, providing trainings to the employees, and having the time to know each other.

The necessity of building trust in merger process is widely emphasized in literature on M\&As (Schraeder and Self, 2003; Weber, 1996; Bourantas and Nicandrou, 1998; Bijlsma-Frankema, 2001). However, trust suffers the most during cross-border acquisitions. Therefore, Nikandrou et al. (2000) insist on establishing frequent communication between acquirer and acquired employees.

The review of literature presented above shows that major barriers in cross-border deals are caused by cultural challenges resulting from differences in both national and organisational cultures. However, are there other sources of barriers to interactions between MNCs' headquarters (HQ) and their local subsidiaries? What approaches to HRM may reduce tensions in mutual relationship? The literature review therefore reveals limitations of existing studies from the point of view of the aim of this paper. These mainly concern a relative lack of focus on foreign subsidiaries established in an acquisition process and European transition economies' experiences. Moreover, there is a need to indicate potential sources and types of barriers to interactions in cross-border acquisitions, understanding of which may contribute to successful HRM in such deals. The subsequent sections should address the identified gap.

\section{Barriers to interactions in cross-border acquisitions, HRM issues}

Basing on the existing literature review and the author's research presented in the subsequent part of this paper, this section provides a framework for managing interpersonal relations in foreign subsidiaries of MNCs established via acquisitions. While in practice, the role of HRM in post-merger integration process is primarily focused on structuring, legal issues, remuneration and pensions (Siegenthaler, 2011), this framework highlights the role of barriers in personnel management in crossborder acquisitions. This concept is based on the assumption that the effective overcome of barriers to cross-border interactions reduces tensions in interpersonal relations (that are cross-cultural interactions) in crossborder acquisitions, which then results in the winning HRM strategies. The term 'the winning HRM strategies' is understood as an ability of the managers to establish an effective and efficient cooperation between their people in the organisation. HRM strategies affect integration process and then M\&A's outcomes which can further influence the abilities of the managers to overcome the barriers. Effective sociocultural integration reflects shared identity, positive attitudes and trust, whereas task integration refers to the capability transfer, resource sharing and learning (Stahl and Voigt, 2008). Unsolved barriers to cross-border interactions may hinder cooperation between the people in an organisation and produce ambiguity in identity, suspiciousness and problems in tasks realisation, which then result in a lack of synergy in a cross-border acquisition.

The framework is proposed to help identify the determinants of successful approaches to managing interactions of people within foreign subsidiaries of MNCs established in an acquisition process. Successful management of cross-border acquisition, including humanrelated issues, requires an in-depth understanding of barriers in management of foreign subsidiaries. Managers should learn how to surmount such obstacles to improve interpersonal relations as well as the outcomes of a MNC.

Figure 1 summarizes the proposed framework. The research findings presented in the subsequent part of this paper concentrated on the analysis of various source of tensions (barriers) to interpersonal relationships, while the interviewees were also asked about approaches that helped to maintain cooperation in their interpersonal interactions with the foreign staff in their local subsidiaries, with the other affiliates and the parent companies as well.

Barriers to interactions in cross-border acquisitions are defined as factors caused by culture (national and organisational) and other determinants that hinder effective operating of a MNC considered as a whole and its parts, that is foreign subsidiaries (Rozkwitalska, 2011) or paraphrasing, such a barrier can be regarded as any obstacle that may impede interactions among staff in a 


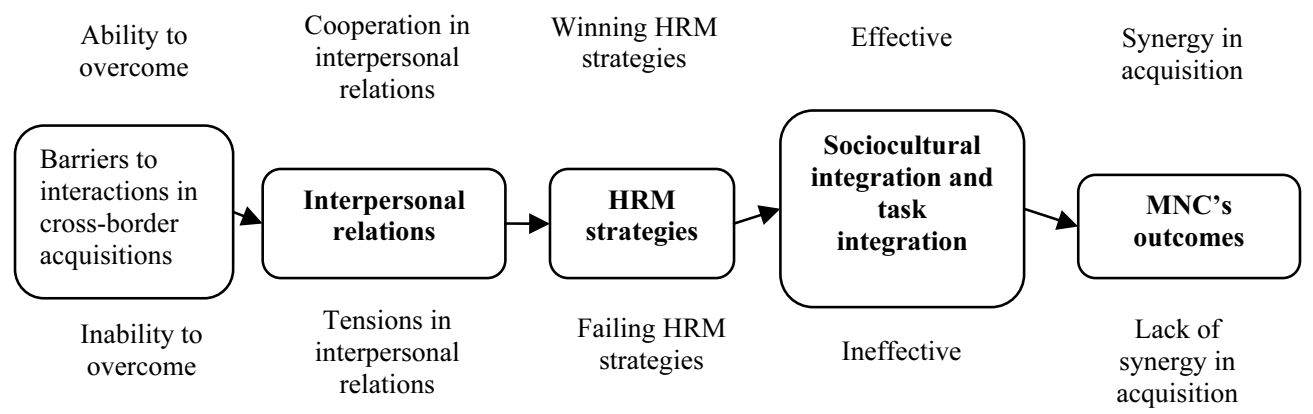

Figure 1. Framework for managing interpersonal relations in foreign subsidiaries of MNCs established via acquisitions

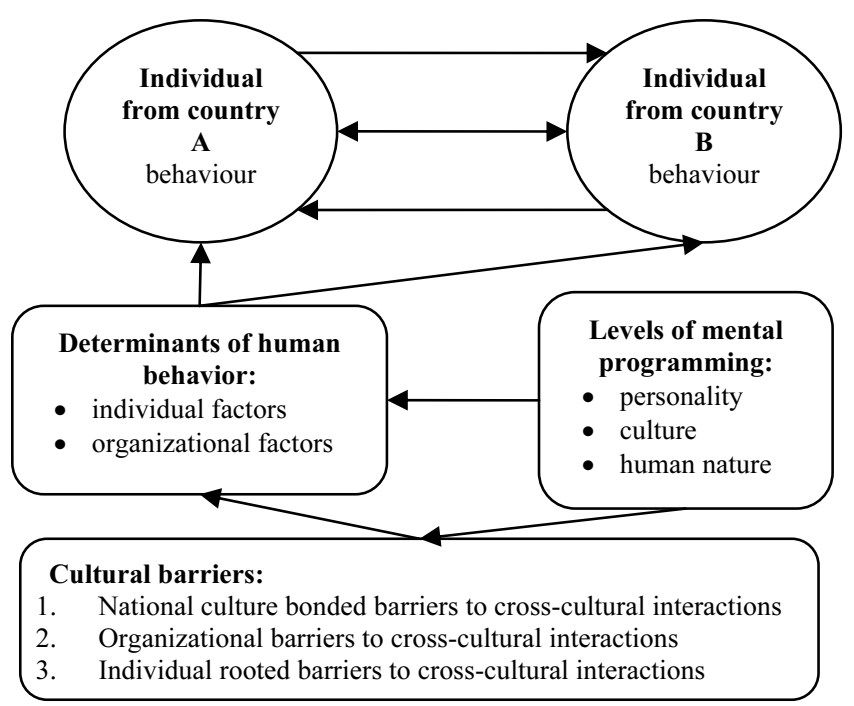

Figure 2. Concept of cross-cultural interactions and sources of barriers to interactions in cross-border acquisitions

cross-border acquisition. Such obstacles hinder an ability to reach goals in a MNC and lower effectiveness of its subsidiaries. The concept of barriers to interactions in cross-border acquisitions is based on a model of human behaviour. Figure 2 summarizes this approach.

Cross-cultural interactions are defined as reciprocal influence (action) of an individual who is a representative of a given national or organizational culture(s) on other individual(s) who is(are) representative(s) of different national or organizational culture(s) (Rozkwitalska, 2011). Figure 2 summarizes the primary determinants of human actions. These are individual factors, such as attitudes, perception, motivation, and individual characteristics (e.g. knowledge, skills, abilities, and intelligence level) and organizational factors like organizational culture, an organization's characteristics, decisions and actions made by the managers, and organizational solutions reflected in processes, systems, methods, regulations etc. (Rozkwitalska, 2011). These are further influenced by the three levels of mental programming of individuals (Hofstede, 2001). Therefore, the three sources of barriers to interactions in cross-border acquisitions can be identified (Rozkwitalska, 2011):
1. National culture bonded barriers to interactions as a result of mental programming of an individual by the national culture. This category includes several types of barriers, namely cultural distance and its effect in the form of cultural shock, cultural stereotypes and auto-stereotypes that can intensify cultural shock or be a result of cultural shock, prejudices that are negative consequences of stereotypes and auto-stereotypes, and national ethnocentrism. National culture bonded barriers affect perceptions of individuals in cross-cultural settings and then their attitudes and behaviours.

2. Organizational barriers to interactions in crossborder acquisitions include several organizational factors like:

- MNC's headquarters' characteristics and failures: institutional ethnocentrism, strategic mindset and approaches to managing cultural diversity not adjusted to the local environment, an insufficient level of international experience, mistakes made in strategic choices, and not adapted organisational solutions,

- a cultural gap that reflects differences in organisational cultures between an acquirer and an acquired company and leads to a double-layered acculturation of expatriates, 
- subsidiary's traits including ethnocentrism or the xenophile level, insufficient international experience, self-perception.

The framework assumes that 'organizational barriers form the boundaries within which human actions take place' (Rozkwitalska, 2011, p. 129). They can facilitate or hamper interactions in cross-border acquisitions, consequently strengthen or weaken other barriers (the national culture bonded or individual rooted ones) to such interactions.

3. Individual rooted barriers to interactions in crossborder acquisitions, like: an ethnocentric attitude, inaccurate perception, a low degree of international experience, his or her characteristics (e.g. age, family status, the education level, the health status), an insufficient level of cultural intelligence and cultural competences.

Interpersonal relations in cross-border acquisitions can be affected by all mentioned above sources and types of barriers. It can produce tensions among people who represent different national or organisational cultures. For example, national ethnocentrism may isolate individuals from external influences raising resistance to everything from outside and enhancing 'us-versus-them' thinking. It also hampers changes because it supports conservative and conformist attitudes. Furthermore, it may favour native languages in communications over other languages represented by different nationalities in subsidiaries. With a situation being that, diversity is perceived as a problem and the attitude 'our way is the best way' prevails (Adler and Gundersen, 2008). Furthering consequence, such a phenomenon increases human-related problems and reduces morale in subsidiaries, especially if they act as active or autonomous units (Yu, 2005). National ethnocentrism can be reinforced by institutional ethnocentrism that is 'the persistence of structures, processes and management mentalities imposed by the parent organization on overseas affiliates, even when it is not appropriate to do so' (Johnson et al., 2006). In the context of cross-border acquisitions, institutional ethnocentrism involves imposing on an acquired company an acquirer's way of doing things including HRM practices. It also impedes a development of cultural competences by expatriates, since they need organisational support. Finally, it hampers cooperation between people representing different approaches since it negatively affects abilities of individuals both the managers and the employees to respond in cross-cultural settings accordingly (Johnson et al., 2006). Entering overseas markets via crossborder acquisitions involves so-called 'double-layered acculturation' of expatriates, namely 'adjustment to both a foreign national and an alien corporate culture' (Barkema et al., 1996). Thus, integration of cultures in cross-border acquisitions encounters more challenges than such a deal within a single country. Moreover, Zhu and Huang (2007) prove that organisational culture differences are easier to solve than national culture differences. Interpersonal relations in cross-border acquisitions depend on behaviours of the individuals involved in cross-cultural interactions, proving that individual rooted barriers also affect interpersonal relations. HRM practices are directed at people and should enhance their cultural competences.

\section{Research method and sample characteristics}

The summary of the study presented in the subsequent section is based on the author's research that was conducted in foreign subsidiaries of MNCs operating in Poland in most cases among top and middle level managers at the end of the year 2009. The main research was named: 'Cultural barriers in functioning of MNC's foreign subsidiaries located in Poland'. The study was broader in scope than the empirical findings presented in this paper and focused on the analysis of selected crosscultural problems in foreign subsidiaries. The aim of the research was to gain insight into the barriers to crosscultural interactions in MNCs' subsidiaries. Its three goals were as the following (Rozkwitalska, 2011a):

- the identification of sources of the barriers to crosscultural interactions and areas of their occurrence in MNCs' foreign subsidiaries,

- the assessment of significance of the barriers from the point of view of the interviewees,

- the analysis of the approaches applied by the interviewees directed at identifying and overcoming barriers to cross-cultural interactions.

Figure 3 describes the research questions of the main project which also helped to collect useful data from the angle of issues presented in this paper (Rozkwitalska, 2011a).

For the purpose of the research portrayed here, foreign subsidiaries were defined as entities where a MNC owns more than 50 percent of equity stake, whereas a multinational company is an entity that has at least two direct investment enterprises in two various countries (Rozkwitalska, 2011).

The non-probabilistic sample in the main study consisted of 48 subsidiaries, while half of them were established via acquisitions and this section and the next one report only the research findings concerning them. A non-probabilistic sample was chosen due to the lack of data that would allow separating a foreign subsidiary of a MNC from a foreign subsidiary that does not belong to a MNC. The capital origin in these entities was mainly European (almost 70 percent), North-American (6 companies) and Asian. Approximately 30 percent of European subsidiaries had mixed capital. With regard to size, the sample mostly consisted of large incorporated subsidiaries (more than 65 percent of the sample), whereas medium-sized enterprises accounted for 26 percent of the sample. They represented various sectors: mainly services (56.5 percent of the sample) and manufacturing. Nearly 40 percent of the subsidiaries have been operating as joint venture establishments. Most of the entities in the sample (82 percent) have been running their operations for at least 5 years, including $1 / 5$ subsidiaries in the operation for 15 years. They have belonged to the MNCs with long-lasting international presence. 


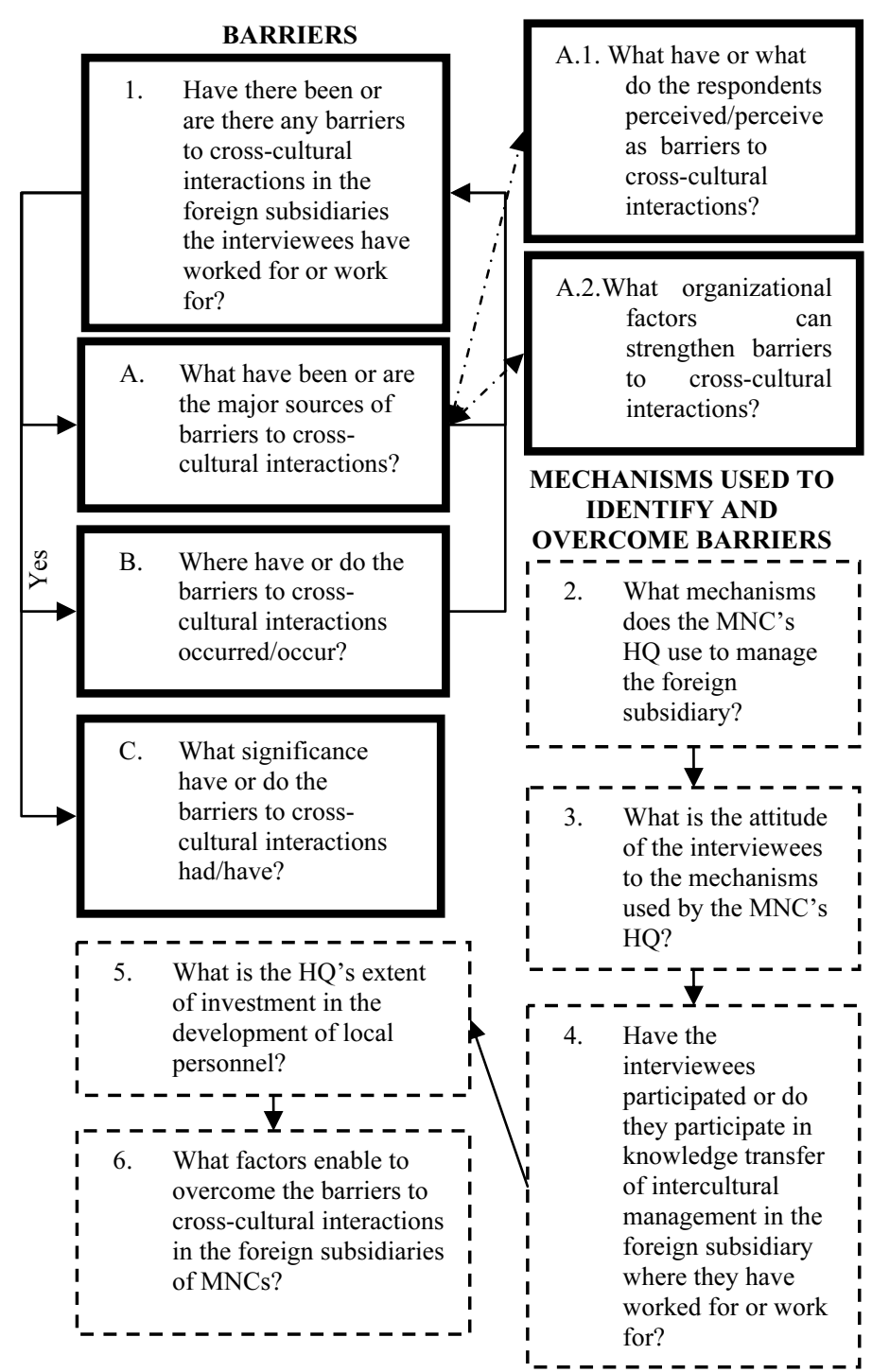

Figure 3. Research questions in the study 'Cultural barriers in functioning of MNC's foreign subsidiaries located in Poland'

The empirical findings reported in this section are based on information obtained from 23 senior managers (73.9 percent of the sample) and specialists working in MNCs' subsidiaries, i.e. acquired companies. The information was collected via personal semi-structured indepth interviews which lasted approximately 1.5 hours and were conducted in subsidiaries' offices in most cases. The issues that were discussed reflected the research questions portrayed in Figure 3. Moreover, each interview included some initial questions regarding company characteristics e.g. capital origin, size, level of employment, type (i.e. greenfield investment or acquisition). The very nature of semi-structured in-depth interviews allows an interviewer to ask additional questions that deepen issues under discussion. Semi-structured interviews were considered the most appropriate approach due to giving the interviewees the opportunity to reflect their own experience in and attitudes to their interactions with foreigners in cross- border acquisitions. Furthermore, as emphasized by Kuhlmann and Hutchings (2010), open-ended interview questions in semi-structured in depth interviews allow respondents to contribute new aspects to the study which may not have been considered earlier by the research. The method was to ensure an in-depth understanding of the still poorly analysed area of interactions with foreigners in multinational subsidiaries. The chosen method facilitates obtaining detailed and accurate observations. However, the qualitative research does not enable to draw valid conclusions concerning the whole research population, while comparison of the data is also limited (Brenner, 2009; Lodorfos and Boateng, 2006).

The interviewees were mainly in their thirties, men, Poles and two foreigners. They represented various functional departments. The respondents were the subsidiaries' staff since the author intended to emphasize the local units' perspective on the problem, especially the 
local managers' viewpoint. Six people included in the sample were directly involved in the strategic decisions making concerning acquisitions in their respective subsidiaries as the managing directors or owners in the target companies.

Secondary data were also collected from the official government statistical reports and databases, the companies' websites and other Internet sources such as press release or online community services. All obtained data were transcribed to facilitate interpretation. Then the qualitative content analysis was conducted that consists of three steps: summarising, explicating and structuring (Brenner, 2009). The second step also included consulting the relevant literature, yet triangulation of the data was limited mainly to this step due to difficulty in attracting more respondents from a single company.

Two out of ten cross-cultural interactions that were scrutinized included direct personal relationships, e.g. interactions within multi-cultural and virtual teams, subordinate-superior relationships, office contacts with employees in other foreign affiliates of a MNC, internships and trainings in other MNC's units, company meetings, etc. In most cases the interviewees experienced during their work in the subsidiaries more than seven various types of cross-cultural interactions. Therefore, they can be perceived as a reliable source of information in humanrelated issues in foreign subsidiaries established via acquisitions. Since the majority of the respondents had international experience before their present jobs, this could have affected their barriers' awareness and the level of their cultural competences.

\section{Lessons from cross-border acquisitions in Poland, HRM issues}

The empirical findings presented in this section reflect answers to the research questions described in Figure 3.

During the interviews respondents were able to indicate some differences in behaviours of various nationalities which they worked with and, as they reported, this fact caused some problems in their daily operations, e.g. in HRM approaches, working styles, formalisation needs, discussions during meetings:

Lively gesticulation and uproariousness of the French made some of the meeting's member nervous. They found it as an attack and, instead of looking for a solution, they stiffened in their positions. They did not have knowledge of typical French expressiveness and their specific verbal communication style. Moreover, the French were in their element speaking native language (from an interview).

The differences between the national cultures were sometimes viewed as a valuable factor improving the personnel relations, e.g. a manager in a subsidiary of a Finish MNC basing on his working experience prised Finns for their trust in people, which contributed to the mutually effective human relationships. Some of the interviewees located differences in individuals' behaviour mainly in their various personalities, which emphasizes how difficult it is in cross-cultural settings to separate behaviours caused by nationalities from those influenced by personality traits.

The interviewees indicated obstacles to effective functioning of their subsidiaries within MNCs' system that can be associated with organisational barriers. These included institutional ethnocentrism in a form of unreasonable imposing on the acquired subsidiaries methods, systems and processes which were not adjusted to the Polish situation, ignoring local ideas, treating the local staff as inferior and not qualified enough to understand the modern market demand due to the socialistic heritage of Poles; a lack of clear strategy and local adaptation; and a culture gap.

The adaptation problems increased a difficulty in an integration process in a subsidiary of a Mexican MNC. As an interviewee observed:

The corporation came up with a new HR philosophy. It assumed, among other things, outsourcing and manpowering. These markets are still under construction in Poland. Ensuring such services in some location can be problematic (Rozkwitalska, 2011a, pp. 168-169).

The integration process after the merger revealed obstacles due to a culture gap, as reported during an interview:

Generally, with regard to the integration process the corporate culture is inconsistent, which causes discrepancies in implementations of common rules, processes and procedures. Relatively, there is a short time after the merger and the corporate culture is not well developed. There are many borrowings from both companies which are incoherent and cause confusion (Rozkwitalska, 2011a, p. 169).

Conflicts between declared values and actual actions along with invalidity of certain values were additional problems in the integration stage. Few interviewees pointed out that MNCs experienced in inorganic growth faced fewer problems in integration of the acquirer and the target company cultures. One respondent reported that the process was better facilitated partially because there was the harmonization committee established in the MNC for the purpose of unifying the procedures within the whole company. In another subsidiary, the Poles were involved in the committee's work which reduced resistance to the implementation of organisational culture. Another interviewee highlighted a consistent implementation of the company's procedure as an enabling factor in the post integration period. Such effective integration of organisational cultures enabled a long-lasting cooperation before the acquisition as was indicated by a manager in a Polish-Finnish subsidiary. The unit was a subcontractor of the Finnish MNC and had copied the structures and methods before the deal was completed. However, some problems in the integration process retained and could be associated with the size of the differences between the subsidiary and the MNC. The Polish party did not want to accept the excessive control via a reporting system that caused delay in the task performance. Additionally, according to the respondent, too frequent contacts of the Polish staff with the headquarters negatively affected their 
morale since the slow pace of work there. Thus, they implemented a tactic of avoiding contacts with the central. In a Polish-Italian subsidiary the integration problems were more common. As the interviewee observed, the HQ managers tried to impose their own approach on every aspect of their Polish unit. They were not aware of the situation in the transition economy and the problems they would have to face. It caused tensions in the interpersonal relations - conflicts occurred frequently and they were very emotional and violent. The expatriate who managed this subsidiary was in a difficult position being under conflicting pressure from the central and the subsidiary's staff. Finally, the headquarters gave in to their Polish party's requirements which since then was granted more autonomy, curing the mutual relations. Nevertheless, this institutional ethnocentrism might have led to so called 'organisational blindness' when subsidiaries formally do things in headquarters' way while in fact they do things in their own way. Such behaviour was observed and, although being potentially harmful to a MNC, it was accepted by a few interviewees.

The acquisitions presented above caused the employees' stress and raised negative feelings toward the acquired company. The national culture bonded, the organisational and individual rooted barriers boosted so as human related problems:

Regardless of an approach, the post merger period is always the toughest (the fear of losing a job position, mistrust to the acquirer with regard to his plans, etc.). This period is the most stressful and frequently even drastic time in an acquired company. It is universally known that the Polish firms had an excess of personnel and each acquisition here caused a lay-off (Rozkwitalska, 2011a, p. 169).

As stated above, the employees' stress in the crossborder acquisitions in Poland could have increased due to downsizing of the acquired subsidiaries. It happened also due to the fact that CEE's countries might be viewed as a low-cost location. This approach may be more typical of American acquisitions since it was noticed by the interviewees from subsidiaries of American MNCs. Nevertheless, more studies are required to confirm this observation since only five subsidiaries in the sample had an American stake in the capital.

The integration process can be shorter and more successful when high-qualified expatriates are sent to their subsidiaries to act as liaisons enabling an effective transfer of knowledge and culture. Unfortunately, CEE's countries seem to be not always attractive to foreigners, as noticed by the interviewees. Thus, as several of them observed, the 'second-class' managers were sometimes sent here. This raised mistrust and suspiciousness in the acquired companies. The necessity to cover an expatriate's pay package by the subsidiary caused additional problems in mutual relations. Moreover, an expatriate might not find acceptance, since:

Sending expatriates to CEE's countries can be reasoned by a need of control resulting from a lack of trust to the locale cadre. There is not any longer a shortage of qualified personnel on CEE's markets nowadays (Rozkwitalska, 2011a, p. 171).

Communication barriers seem to be a serious problem during all the stages in acquisitions:

It was common to use interpreters or bilingual expats. It also caused misunderstandings because an interpreter was not neutral and it was expected that he or she would take the position. The translations were frequently emotional and culture-bound (Rozkwitalska, 2011a, p. 175).

To overcome these hurdles during and after the integration stage a MNC need to invest in the development of the locale cadre, including communication skills in both the subsidiaries and headquarters. The research highlighted a fact that the costs of trainings, including language trainings, and the cost of translations were shifted to the subsidiaries' budgets, which created an organisational barrier to interactions in cross-border acquisitions. The efficiency pressure forced the local units, among other things, to reduce the costs that created obstacles in efficient communication. An additional problem lay in the insufficient level of language skills in other units of the MNCs' system and reluctance to use the company's functional language. Moreover, the research revealed low attractiveness to the subsidiaries' employees of staff mobility programs that could have created additional organisational barriers to the integration and interpersonal relations in M\&As due to the obstacles in the socialisation process. Several interviewees claimed that HRM practices, especially the promotion decisions, were ethnocentric and some trainings were poorly adapted to the local requirements. Less than a half of the subsidiaries in the sample were involved in the knowledge transfer about the cross-cultural management that, if implemented, could improve mutual interactions in cross-border acquisitions.

Many acquisitions of those analyzed caused fluctuations, especially in the presence of barriers to interactions in the subsidiaries. If it was not restricted by the contracts and if the labour unions were weak or absent, the acquirers typically used to replace the older staff with the younger cadre gradually, usually a collage graduates. This tactic initially created tensions. However, it allowed instilling the company's culture faster. The expatriates' representation in the board of directors was another usual approach to managing the acquired companies. Although their qualifications were appreciated in most cases, the interviewees expected that the expatriates would prepare their local successors. This strategy contributed to the growth of morale among the locals. Another successful approach was observed in a subsidiary of a French MNC, where the expatriates tried not to stand out of the Polish staff and drove cars that Poles could afford too.

\section{Conclusions}

As portrayed in the former section, cross-border acquisitions face barriers that affect interpersonal relations and MNCs' outcomes. In 2 of 24 analyzed cases the problems in human interactions were so huge that they 
contributed to the termination of cooperation between the companies. Some barriers were typical of the privatisation process of the state-owned companies in Poland and may no longer occur in the future acquisitions in this country, as an interviewee observed:

Our company culture was based on collectivism and defence against all new ideas. The employees believed: 'If they (the board of directors) implement something new, it will be beneficial to them, not to us'. (...) The staff, especially less-qualified workers, had not had any prior experiences with foreigners. The claims and the labour unions - these hampered an implementation of solutions even those accepted by the Polish managers. However, I think that if it was a young organisation, everything would look better.

Some propositions can be drawn on what determines the winning HRM strategies in cross-border acquisitions with respect to subsidiaries' perspective. These propositions reflect the cases analysed in the paper and may reduce all sources of barriers to interactions between the HQ and its local units in cross-border acquisitions. Moreover, they answer research question 6 (Figure 4) with regards to those subsidiaries that were established via acquisition. These propositions are as follows:

1. Prior experiences of a MNC in cross-border acquisitions is of vital importance, consequently such experience may lower human related problems.

2. Cooperation before the deal with prior implementation of certain systems and methods contribute to knowing each other and enable effective integration. A subsidiary needs to be active.

3. Use of a harmonization committee with the local staff participation to ensure a better adaptation.

4. Pre-tested and flexibly implemented a MNC's procedures may facilitate the integration process.

5. Avoiding an ethnocentric attitude is crucial in building trustful interactions between people.

6. Sending high-qualified expatriates to the subsidiaries who train their local successors.

7. Developing the local staff to facilitate the socialization process.

The framework for managing interpersonal relations in subsidiaries established in cross-border acquisitions along with the research findings presented in the previous sections can contribute to a better understanding of crosscultural issues in acquisitions in transition economies. However, future research is required and quantitative method should be applied to a larger sample to obtain more cases along with the additional qualitative studies.

\section{References}

1. Adler, N.J., \& Gundersen, A. (2008). International Dimensions of Organizational Behaviors. South-Western: Cenage Learning. Mason.

2. Antila, E.M., \& Kakkonen, A. (2008). Factors affecting the role of HR managers in international mergers and acquisitions. A multiple case study. Personnel Review, 37, (3), 280-299. http://dx.doi.org/10.1108/00483480810862279
3. Barkema, H.G., Bell, J.H.J., \& Pennings, J.M. (1996). Foreign entry, cultural barriers, and learning. Strategic Management Journal, 17, 151-166. http://dx.doi.org/10.1002/(SICI)10970266(199602)17:2<151::AID-SMJ799>3.0.CO;2-Z

4. Bijlsma-Frankema, K. (2001). On managing cultural integration and cultural change processes in merger and acquisition. Journal of European Studies, 25, 192-207.

5. Birkinshaw, J. (2003). Strategy and Management in MNE Subsidiaries. In A.M. Rugman, T.L. Brewer (Eds.). The Oxford Handbook of International Business, 380-401. NY: Oxford University Press.

6. Bourantas, D., \& Nicandrou, I.I. (1998). Modelling post-acquisition employee behaviour: typology and determining factors. Employee Relations, 20, (1), 73-91. http://dx.doi.org/10.1108/01425459810369841

7. Brenner, B. (2009). Management Control in Central and Eastern European Subsidiaries. Hampshire: Palgrave Macmillan.

8. Brock, D.M., Barry, D., \& Thomas, D.C. (2000). Your forward is our reverse, your right, our wrong: rethinking multinational planning processes in light of national culture. International Business Review, 9, (6), 687-701. http://dx.doi.org/10.1016/S09695931(00)00027-5

9. Buckley, P.J., \& Casson, M. (1996). An economic model of international joint venture strategy. Journal of International Business Studies, 22, (4) 579-601. http://dx.doi.org/10.1057/palgrave.jibs.8490154

10. Cartwright, S., \& Cooper, L.C. (1993). The role of culture compatibility in successful organisation. The Academy of Management Executive, 34, 67-80.

11. Davy, A.J., Kinicki, A., Kilroy, J., \& Scheck, C. (1988). After the merger: dealing with people's uncertainty. Training and Development Journal, 42, 57-61.

12. Hofstede, G. (2001). Culture's Consequences: Comparing Values. Behaviors. Institutions and Organizations across Nations. Thousand Oaks, California: Sage.

13. Huang, C.T.W., \& Kleiner, B.H. (2004). New Developments Concerning Managing Mergers and Acquisitions. Management Research News, 27, (4/5), 54-62. http://dx.doi.org/10.1108/01409170410784473

14. Johnson, J.P., Lenartowicz, T., \& Apud, S. (2006). Cross-cultural competence in international business: toward a definition and a model. Journal of International Business Studies, 37, 525-543. http://dx.doi.org/10.1057/palgrave.jibs.8400205

15. Kanter, R.M., \& Corn, R.I. (1994). Do Cultural Differences Make a Business Difference? Contextual Factors Affecting Cross-cultural Relationship Success. Journal of Management Development, 13, (2), 5-23. http://dx.doi.org/10.1108/02621719410050219

16. Krishnan, R.A., Joshi, S., \& Krishnan, H. (2004). The influence of mergers on firms' product mix strategies. Strategic Management Journal, 25, (6), 587-611. http://dx.doi.org/10.1002/smj.410

17. Kühlmann, T., \& Hutchings, K. (2010). Expatriate assignments vs localization of management in China: Staffing choices of Australian and German companies. Career Development International, 15, 1, 20-38. http://dx.doi.org/10.1108/13620431011020871

18. Lodorfos, G., \& Boateng, A. (2006). The role of culture in the merger and acquisition process. Evidence from the European chemical industry. Management Decision, 44, (10), 1405-1421. http://dx.doi.org/10.1108/00251740610715722 
Social Sciences /

Socialiniai mokslai. 2012. Nr. 3 (77)

19. Nikandrou, I., Papalexandris, N., \& Bourantas, D. (2000). Gaining employee trust after acquisition: Implications for managerial action. Employee Relations, 22, 4, 334-355. http://dx.doi.org/10.1108/01425450010340344

20. Rozkwitalska, M. (2011). Barriers of cross-cultural interactions according to the research findings. Journal of Intercultural Management, 3, (2), 127-142.

21. Rozkwitalska, M. (2011a). Bariery w zarzadzaniu międzykulturowym. Perspektywa filii zagranicznych korporacji trnansnarodowych. Warszawa: Oficyna a Wolters Kluwer business.

22. Salama, A., Holland, W., \& Vinten, G. (2003). Challenges and opportunities in mergers and acquisitions: three international case studies - Deutsche Bank-Bankers Trust; British Petroleum-Amoco; Ford-Volvo. Journal of European Industrial Training, 27, (6), 313321. http://dx.doi.org/10.1108/03090590310479947

23. Schraeder, M., \& Self, D.R. (2003). Enhancing the success of mergers and acquisitions: an organizational culture perspective. Management Decision, 41, (5), 511-522. http://dx.doi.org/10.1108/00251740310479359

24. Schuler, R.S., \& Jackson, S.E. (2001). HR issues and activities in mergers and acquisitions. European Management Journal, 19, (3), 239-53. http://dx.doi.org/10.1016/S0263-2373(01)00021-4

25. Shook, L.V., \& Roth, G. (2011). Downsizings. Mergers and acquisitions. Perspectives of human resource development practitioners. Journal of European Industrial Training, 35, (2), 135 153. http://dx.doi.org/10.1108/03090591111109343

26. Siegenthaler, P.J. (2011). What role for HR during mergers and acquisitions? Human Resource Management International Digest, 19, (1), 4-6. http://dx.doi.org/10.1108/09670731111101507

27. Stahl, G.K., \& Voigt, A. (2008). Do Cultural Differences Matter in Mergers and Acquisitions? A Tentative Model and Examination. Organization Science, 19, (1), 160-176. http://dx.doi.org/10.1287/orsc.1070.0270

28. Stahl, G.K. (2006). Synergy springs from cultural revolution. Financial Times, 6 October.

29. Steger, T., Lang, R., \& Groeger, F. (2009). Expatriates and the institutionalisation of HRM practices. Baltic Journal of Management, 6, (1), http://dx.doi.org/10.1108/17465261111100923

30. Weber, Y. (1996). Corporate culture fit and performance in mergers and acquisitions. Human Relations, 49, (9), 1181-95. http://dx.doi.org/10.1177/001872679604900903

31. Yu, M. (2005). Taiwan Multinational Companies and the Effects Fitness between Subsidiary Strategic Roles and Organizational Configuration on Business Performance: Moderating Cultural Differences. The Journal of American Academy of Business, 7, (1), 213-218.

32. Zue, Z., \& Huang, H. (2007). The Cultural Integration in the Process of Cross-border Mergers and Acquisitions. International Management Review, 3, (2), 40-44.

\section{Rozkwitalska}

Žmogiškụjụ ištekliụ valdymo strategijos siekiant ịveikti multinacionalinių kompanijų tarptautinių įsigijimų barjerus: Lenkijos multinacionalinių dukterinių kompanijų atvejis

Santrauka

Integracijos procesai, vykstantys įsigijus užsienio dukterinę kompaniją gali atskleisti žmogiškujų išteklių valdymo barjerus, kylančias
M. Rozkwitalska. Human Resource Management Strategies for Overcoming the Barriers in Cross-border Acquisitions of Multinational Companies: the Case of Multinational Subsidiaries in Poland

dèl kultūrinių skirtumų, organizacinių ar individualių barjerų. Tokie iššūkiai tampa dar reikšmingesni, kai sandèrius sudaro kompanijos iš išsivysčiusios ir besivystančios ekonomikos šalių. Tarptautiniai ịsigijimai padidina šių barjerų tikimybę dèl centrinès būstinès, esančios kitoje šalyje, komunikacijos su dukterinėmis ịmonėmis, esančiomis kitose šalyse. Todèl straipsnio tikslas yra išanalizuoti kai kurias žmogiškuju išteklių valdymo strategijas, leidžiančias sėkmingai ir nesėkmingai veikti tarptautinių i̊sigijimų kontekste. Straipsnyje analizuojamas Lenkijos multinacionaliniu dukteriniu kompaniju atvejis. Taip pat straipsnio autore siekia nustatyti efektyvios komunikacijos valdymo dukterinèse multinacionalinių užsienio kompanijų įmonèse, veikiančiose Lenkijoje, veiksnius.

Studijų, nagrinėjančių integracijos procesus, vykstančius ịsigijus užsienio dukterinę kompaniją Centrinès ir Rytų Europos pereinamojo laikotarpio ekonomikose, nèra daug. Be to, nagrinejjant tarptautinius sanderius ịsigijimuose, dukterinès kompanijos perspektyva nèra ịprasta.

Straipsnyje pateikiamos teorinès ir empirinès ịžvalgos gali padèti geriau suprasti tarpkultūrinius iššūkius, susijusius su tarptautiniais ịsigijimais pereinamojo laikotarpio ekonomikose. Straipsnyje akcentuojami tarptautiniams ịsigijimams būdingų sąveikų barjerų šaltiniai ir tipai, pateikiami empiriniais tyrimo duomenimis pagrịsti būdai, kaip vadovauti integracijos procesui. Taip pat yra siūloma tarpasmeninių santykių valdymo struktūra, akcentuojant tarptautinių ịsigijimų būdu ikurtas užsienio dukterines kompanijas.

Straipsnyje akcentuojama, kad pagrindiniai barjerai tarptautiniuose sandèriuose yra kultūriniai iššūkiai, nulemti nacionalinių ir organizacinių skirtumų. Tačiau autorẻ kelia ir šiuos klausimus: ar egzistuoja kiti barjerų šaltiniai sąveikose tarp multinacionalinių kompanijų centrinių būstinių ir ju dukterinių kompanijų? Kokia žmogiškuju ištekliu valdymo traktuote gali sumažinti ịtampas abipusiuose santykiuose? Siekiant atsakyti ị šiuos klausimus, pagrindžiamas tarpkultūrinių sąveikų tarptautiniuose ịsigijimuose konceptas. Tarpkultūrinių sąveikų tarptautiniuose ìsigijimuose barjerai apibrěžiami kaip veiksniai, kurie yra nulemti kultūros (nacionalinès ir organizacinès) ir kitu veiksnių, trikdančiu efektyvią multinacionalinès įmonès veiklą. Tokiu barjeru tampa bet kuri kliūtis, apsunkinanti personalo sąveiką tarptautinio įsigijimo metu, trukdanti siekti multinacionalinès kompanijos ir jos dukterinių įmonių tikslų. Straipsnyje pateikiami šie barjerų šaltiniai: barjerai susiję su nacionaline kultūra (apima ir barjerus, kuriuos sukelia kultūriniai skirtumai tarp įsigyjančio subjekto ir įsigytos kompanijos kultūrų drauge su atitinkamais stereotipais, kultūriniais šokais, išankstinėmis nuostatomis), organizaciniai barjerai (kadangi sąveikaujama konkretaus organizacijos padalinio ribose), individualūs barjerai (kadangi pagrindiniai saveikos elementai yra jose dalyvaujantys individai). Organizaciniams barjerams taip pat priklauso vadinamasis institucinis etnocentrizmas, strateginis mąstymas ir lokaliam kontekstui neadaptuotos kultūriniu skirtumu valdymo prieigos, kultūrinis atotrūkis ar nepakankamas tarptautinių patirčiu lygmuo. Individo lygmens barjerai atspindi žmoniu, dalyvaujančiu tarpkultūrinėse saveikose, charakteristikas ir yra nulemti požiūrio, suvokimo, patirties, kultūrinès inteligencijos ir kultūrinès kompetencijos lygio.

Straipsnyje daroma prielaida, kad multinacionalinių kompanijų vadybininkai turetų ịveikti šiuos barjerus, siekdami pagerinti bendradarbiavimą tarp centrinès būstinès ir įsigytos dukterinès kompanijos. Tokiu būdu bus prisidedama prie teigiamų multinacionalinès kompanijos veiklos rezultatų, pasiektų dèl efektyvių tarpasmeninių ryšių.

Straipsnyje pristatomas atvejis remiasi 48 giluminiais interviu, atliktais Lenkijoje veikiančiose multinacionalinių kompanijų dukterinėse įmonèse; 24 ịmonès buvo ịkurtos kaip tarptautinių ịsigijimų rezultatas. Jos atstovavo skirtingus sektorius ir kapitalo šaltinius. Tyrimo informantai buvo multinacionalinèse dukterinèse kompanijose dirbantys vadybininkai ir specialistai iš ịvairias funkcijas atliekančių padalinių, dažniausiai atstovaujančių vidurinị ir aukščiausiajji valdymo lygmenis. Šeši asmenys buvo tiesiogiai susiję su strateginių sprendimų prièmimu, kadangi jie yra ìsigytų kompanijų vykdantieji direktoriai arba savininkai.

Straipsnyje pristatomi empiriniai tyrimo rezultatai buvo gauti 2009 metų pabaigoje atliktos platesnès studijos kontekste. Kokybinė studija nagrinèjo kultūrinius barjerus, būdingus Lenkijoje veikiančių multinacionalinių kompanijų dukterinių imonių interakcijoms. Buvo išsamiai tiriami tarpkultūrinių interakcijų barjerai ir mechanizmai, taikomi jiems įveikti.

Gauti rezultatai leidžia teigti, kad egzistuoja tam tikros žmogiškuju išteklių valdymo traktuotès, galinčios teigiamai paveikti abipusị bendradarbiavimą tarp centrinès būstinès ir dukterinių kompanijų užsienio 
šalyse. Tyrimo imties multinacionalinėms kompanijoms būdinga mažiau su žmogiškuoju veiksniu susijusių problemų. Antra, abipusès pažintys prieš sandèri yra efektyvios integracijos prielaida. Taigi bendradarbiavimas ankstyvose ịsigijimo proceso stadijose turi vykti kartu su išankstiniu tam tikrų sistemų ir metodų diegimu. Be to, dukterinė kompanija turi būti aktyvi nepriklausomai nuo vaidmens, kurị jai priskiria centrinè būstinè. Trečia, siekiant užtikrinti geresnę adaptaciją, multinacionalinei kompanijai rekomenduojama įsteigti harmonizacijos komitetą, kuriame dalyvauja ir vietinio personalo atstovai. Multinacionalinès kompanijos procedūros taip pat gali palengvinti integracijos procesą, tačiau jos turi būti testuojamos ir diegiamos lanksčiai. Prieš diegiant multinacionalinei kompanijai būdingas procedūras, procesus, reikia atsižvelgti ị vietinès aplinkos reikalavimus. Multinacionalinès kompanijos personalas turi vengti etnocentriniu nuostatụ, nes jų nebuvimas yra gyvybiškai svarbus kuriant pasitikejjimu gristus žmoniu tarpusavio santykius. Taip pat personalo atstovai „išeiviai“, jei jie yra aukštos kvalifikacijos, gali dalyvauti palengvinant ịsigijimo procesą vietiniuose padaliniuose. Dukterinès kompanijos darbuotojai gali tikètis, kad „išeiviai“ rengs ju mokymus. Galu gale yra būtina mokyti vietinị personalą tam, kad būtų igalintas efektyvios socializacijos procesas.

Straipsnyje pristatomiems empiriniams rezultatams būdingos tam tikros išlygos. Visų pirma - tai ribotas dukterinių kompanijų, kuriose buvo atliktas tyrimas, skaičius. Imtis buvo netikimybinè, todèl rezultatu negalima generalizuoti. Tolesnis kiekybinis tyrimas leistu identifikuoti daugiau imoniu atveju, kurie, drauge su papildomomis kokybinemis studijomis, leistu labiau issigilinti i žmogiškujjų išteklių valdymo tarptautiniuose ịsigijimuose problemas. Tolesnius tyrimus galima atlikti kitose Centrinès ir Rytu Europos šalyse.

Reikšminiai žodžiai: tarptautiniai ịsigijimai, užsienio kompanijos, barjerai, žmogiškujų išteklių valdymas.

First received: June, 2012

Accepted for publication: September, 2012 